\title{
A. Czupryński
}

Silesian University of Technology, Mechanical Engineering Faculty, The Chair of Welding, Konarskiego 18A Street,44-100 Gliwice, Poland

artur.czuprynski@polsl.pl

\section{SELECTED PROPERTIES OF THERMALLY SPRAYED OXIDE CERAMIC COATINGS}

\begin{abstract}
The article presents the results of the study on exploitation properties of flame sprayed ceramic coatings produced by oxide ceramic material in the form of powder on the aluminum oxide $\mathrm{Al}_{2} \mathrm{O}_{3}$ matrix with $3 \%$ titanium oxide $\mathrm{TiO}_{2}$ addition and also on the zirconium oxide $\left(\mathrm{ZrO}_{2}\right)$ matrix with $30 \%$ calcium oxide $(\mathrm{CaO})$ on the substrate of unalloyed structural steel of S235JR grade. As a primer powder, metallic powder on the base of $\mathrm{Ni}$-Al-Mo has been applied. Plates with dimensions of $5 \times 200 \times 300 \mathrm{~mm}$ and also front surfaces of $40 \times 50 \mathrm{~mm}$ cylinders have been flame sprayed. Spraying of primer coating has been done using RotoTec 80 torch and external specific coating has been done with CastoDyn DS 8000 torch. Investigations of coating properties are based on metallography tests, phase composition research, measurement of microhardness, coating adhesion to the ground research (acc. to EN 582:1996 standard), abrasive wear resistance (acc. to ASTM G65 standard) and erosion wear resistance (acc. to ASTM G76-95 standard) and thermal stroke study. Performed tests have shown that the flame spraying with $97 \% \mathrm{Al}_{2} \mathrm{O}_{3}$ powder containing $3 \% \mathrm{TiO}_{2}$ and also by the powder based on zirconium oxide $\left(\mathrm{ZrO}_{2}\right)$ containing $30 \%$ calcium oxide $(\mathrm{CaO})$ performed in a wide range of technological parameters allow to obtain high quality ceramic coatings with thickness up to ca. $500 \mu \mathrm{m}$ on a steel substrate. The primer coating sprayed with the Ni-Al-Mo powder to the steel substrate and external coatings sprayed has the of mechanical bonding character. The coatings are characterized by high adhesion to the substrate and also high erosion and abrasive wear resistance and the resistance for cyclic thermal stroke.
\end{abstract}

Keywords: Flame spray process, coating, ceramic powder, abrasive wear resistance, erosion wear resistance, adhesion strength

\section{INTRODUCTION}

Thermal spraying methods have developed significantly in the recent years by applying more and more technically advanced heat sources and new coating materials unused to date [1-8]. At present, this technology is used in about $70 \%$ of its industrial applications for manufacturing new parts or devices for which high quality workmanship and appropriate surface properties are required. An improvement in the operating parameters of machine and equipment parts associated with high loads and speeds, causing accelerated wear and the necessity of effective regeneration, has also contributed to the rapid advancement of the thermal spraying technology.

The application of flame sprayed coatings has not only been conducive to multifold enhancement in the durability of protection of steel structures against a corrosive environment, but has also led to the extended working time of textile machinery parts, cast moulds, rollers in steel industry conveyors, parts of pumps and stirrers, plastic injection 
moulders, and has also improved the durability and reliability of power boilers [9]. Sprayed ceramic coatings providing excellent thermal and electrical barriers have been manufactured more and more often due to high corrosion, erosion and wear resistance and hardness and high-temperature creep resistance. Ceramic oxide materials based on aluminium oxide $\mathrm{Al}_{2} \mathrm{O}_{3}$ and zirconium oxide $\mathrm{ZrO}_{2}$ are especially noteworthy. Thermal and electric barrier coatings flame-sprayed with such materials are applied in multiple cases, e.g. for electronic components, insulation parts of ignition plugs and power turbines and high-temperature resistant and heatstroke resistant parts of combustion chambers in modern car and airplane engines [10-12].

\section{EXPERIMENTAL PROCEDURE}

The aim of the conducted investigations was to create technological conditions of flame powder spraying and to compare the operating properties of ceramic coatings produced with $\mathrm{Al}_{2} \mathrm{O}_{3}$ - and $\mathrm{ZrO}_{2}$-based powders on structural unalloyed S235JR steel acc. to EN 10025 2:2004. Powder with the content of $97 \%$ of $\mathrm{Al}_{2} \mathrm{O}_{3}$ and $3 \%$ of $\mathrm{TiO}_{2}$, and powder with the content of $70 \%$ of $\mathrm{ZrO}_{2}$ and $30 \%$ of $\mathrm{CaO}$ was selected for spraying. Binding powder, i.e. NiAl-Mo alloy, was employed as a primer coating.

Table 1. Spraying properties of primer coating with Ni-Al-Mo powder

\begin{tabular}{|l|c|}
\hline Torch type: & RotoTec 80 \\
\hline Acetylene pressure: & $0.7[\mathrm{bar}]$ \\
\hline Oxygen pressure: & $4.0[\mathrm{bar}]$ \\
\hline Distance between torch and sprayed surface: & $200[\mathrm{~mm}]$ \\
\hline Preheating temperature: & $40\left[{ }^{\circ} \mathrm{C}\right]$ \\
\hline Change of torch advancement angle relative to the next coating: & $90^{\mathrm{O}}$ \\
\hline
\end{tabular}

Table 2. Spraying parameters of external coating with aluminum oxide and zirconium oxide matrix

\begin{tabular}{|l|l|}
\hline Torch type & CastoDyn DS 8000 \\
\hline Torch tip: & SSM 30 \\
\hline $\begin{array}{l}\text { Powder flow rate: } 1 . \text { for } 97 \% \mathrm{Al}_{2} \mathrm{O}_{3}+3 \% \mathrm{TiO}_{2} \text { powder } \\
2 . \text { for } 70 \% \mathrm{ZO}_{2}+30 \% \mathrm{CaO} \text { powder }\end{array}$ & $\begin{array}{l}2 \text { (setting acc. to manual) } \\
3 \text { (setting acc. to manual) }\end{array}$ \\
\hline Acetylene pressure & $0.7[$ bar $]$ \\
\hline Oxygen pressure & $4.0[$ bar $]$ \\
\hline Assist gas (compressed air) pressure & $3.0[$ bar $]$ \\
\hline Notes: The required primer coating made with Ni-Al-Mo powder & \\
\hline
\end{tabular}

Plates dimensioned $5 \times 200 \times 300 \mathrm{~mm}$ and the faces of $\varnothing 40 \times 50 \mathrm{~mm}$ cylinders were subjected to a manual flame spraying operation using the two aforementioned powders. The surface of the plates and cylinders was cleaned by shot blasting with abrasive blasting treatment in conformity with EN 13507:2010 requirements immediately prior to the spraying process. Surface cleaning was performed with acute angle chilled cast iron. The spraying process consisted of the following operations: 
- a 50 to $100 \mu \mathrm{m}$ thick primer coating was sprayed with Ni-Al-Mo powder with a RotoTec 80 torch (Table 1),

- an approx. $500 \mu \mathrm{m}$ thick external specific coating was sprayed with $97 \% \mathrm{Al}_{2} \mathrm{O}_{3}+3 \% \mathrm{TiO}_{2}$ powder and $70 \% \mathrm{ZrO}_{2}+30 \% \mathrm{CaO}$ powder using a CastoDyn DS 8000 torch, (Table 2).

\section{RESULTS AND DISCUSSION}

Following the spraying process, the plates with ceramic coatings deposited were cut into samples intended for further examinations. The adhesion tests of the coatings sprayed onto the substrates were performed on cylindrical samples. Metallographic macroscope examinations of the sprayed coating surface were undertaken with a stereomicroscope with the magnification of 4 to 25 times (Fig. 1).

a)

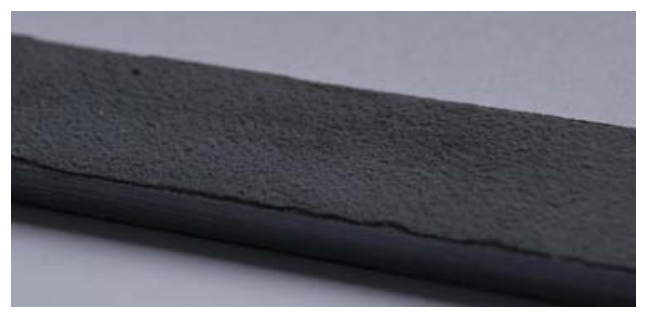

b)

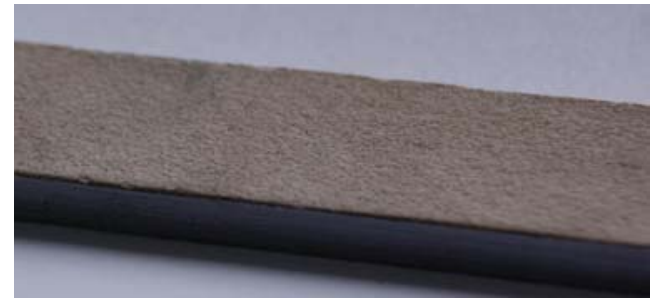

Fig. 1. View of samples flame sprayed with: a) $97 \% \mathrm{Al}_{2} \mathrm{O}_{3}+3 \% \mathrm{TiO}_{2}$ powder; b) $70 \% \mathrm{ZrO}_{2}+30 \% \mathrm{CaO}$ powder

Metallographic microscope examinations were carried out on metallographic microsections perpendicular to the coating, cut from the plates after flame spraying with aluminium oxide and zirconium oxide matrix powder. The structure of the examined coatings was revealed on microsections etched in a $4 \%$ nitric acid solution $\left(\mathrm{HNO}_{3}\right)$ and ethyl alcohol solution $\left(\mathrm{C}_{2} \mathrm{H}_{5} \mathrm{OH}\right)$. Metallographic microscope examinations were performed with the magnification of 100 to 1000 times. The grain size in the plate structure was determined with a comparative method. The thickness of the coatings was determined with the metallographic method in compliance with ISO 1463 1997. A result was represented by average values from ten measurements. The results of metallographic microscope examinations have allowed to evaluate the structure of the base material, primer coating and specific external coating and their thickness after a flame spraying operation (Fig. 2 to Fig. 4).

a)

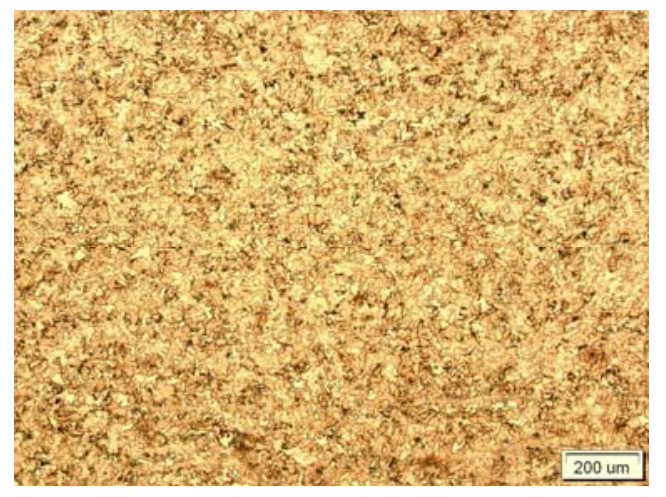

b)



Fig. 2. Fine-grained structure of ferrite with small areas of perlite in the steel subjected to the flame spraying process: a) magn. of $100 x, b)$ magn. of $1000 x$ 
a)

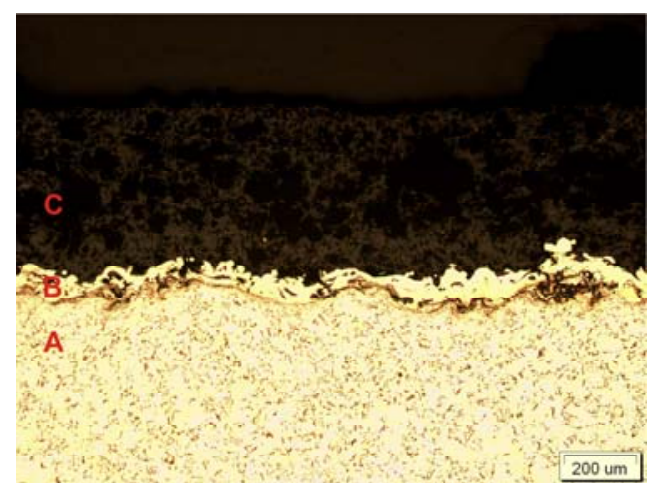

c)

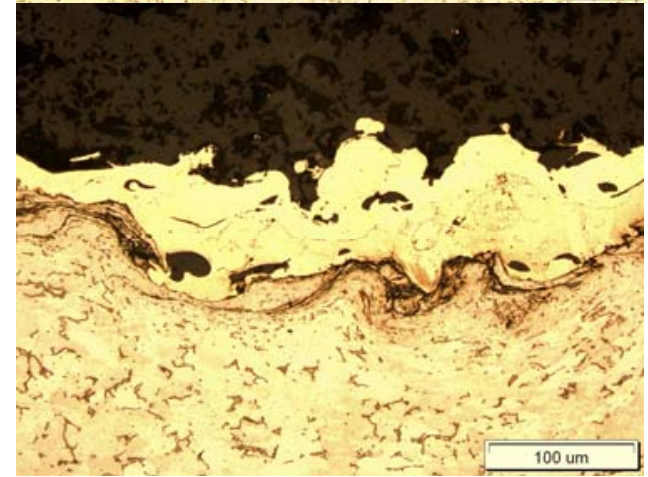

b)

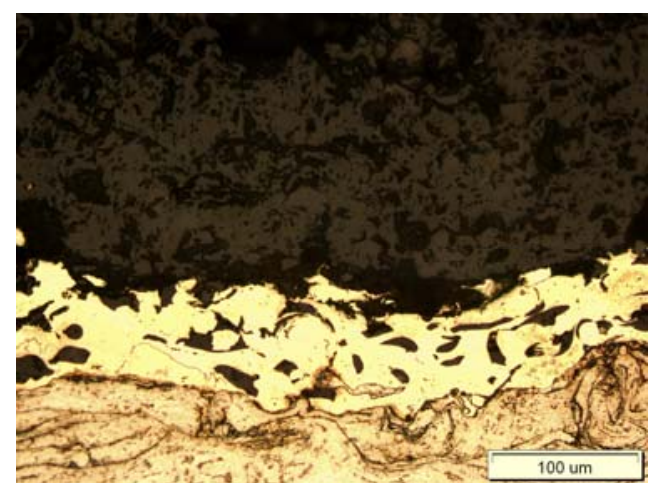

d)

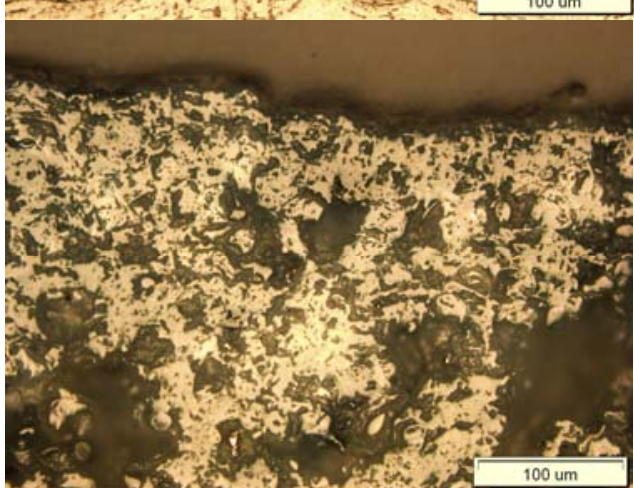

Fig. 3. View after flame spraying with $97 \% \mathrm{Al}_{2} \mathrm{O}_{3}+3 \% \mathrm{TiO}_{2}$ powder: a) structure of specific external coating (C), primer Ni-Al-Mo coating (B) and base material (A), magn. of 100x; b) structure of external coating and image of binding zone of external coating with primer coating, magn. of $400 x ; c)$ structure of primer coating over area of deformed steel with developed surface line, magn. of 400x; d) structure of external coating, magn. of 400x

a)

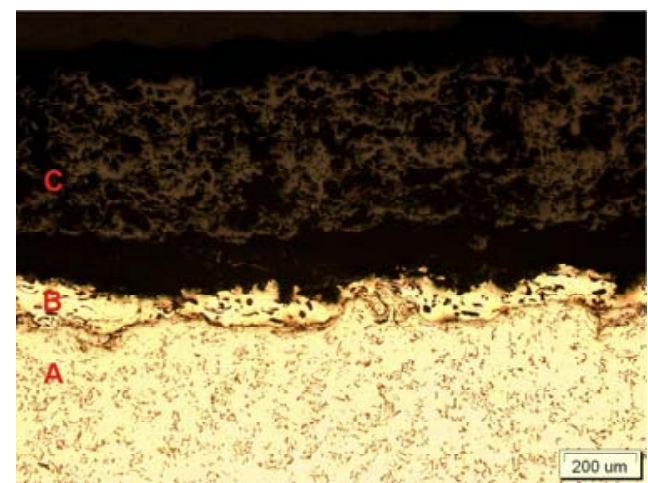

c)



b)



Fig. 4. View after flame spraying with $70 \% \mathrm{ZrO}_{2}+30 \% \mathrm{CaO}$ powder: a) structure of specific external coating (C), primer Ni-Al-Mo coating (B) and base material (A), magn. of 100x; b) structure of external coating with microhollows and image of binding zone of external coating with primer coating, magn. of $400 \mathrm{x} ; \mathrm{c}$ ) structure of primer coating over area of deformed steel with developed surface line, magn. of 400x; d) structure of external coating, magn. of $400 x$ 
A coating hardness measurement was made with the Vickers method. The examinations were carried out in conformity to ISO 6507-1:2007. A load applied during a hardness measurement was between 0.1 and $5 \mathrm{~N}$. A hardness measurement was made at the cross section of the samples with ceramic coatings deposited with $97 \% \mathrm{Al}_{2} \mathrm{O}_{3}+3 \% \mathrm{TiO}_{2}$ and $70 \% \mathrm{ZrO}_{2}+30 \% \mathrm{CaO}$ powder. Fifteen hardness measurements were made on the cross section of the samples, and six measurements were made in the specific external coating $(\mathrm{C})$, three in the primer coating (B) and six in the base material (A), in the microareas marked in Fig. 5.

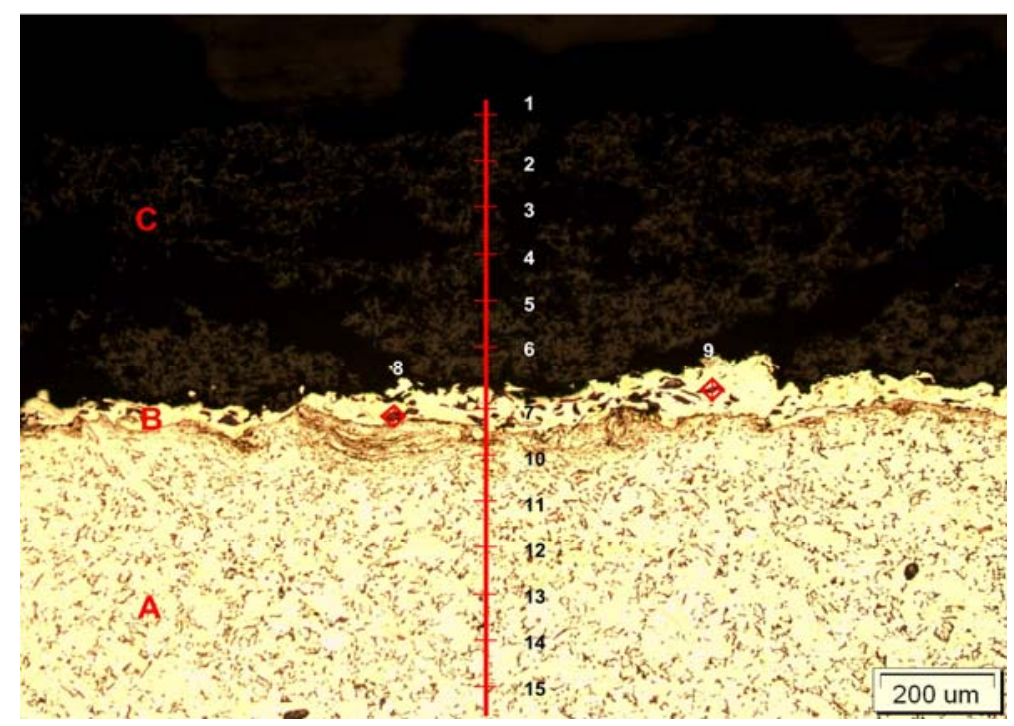

Fig. 5. Diagram of hardness measurements at cross section of sample after flame spraying: C - external specific coating, B - primer coating, A - substrate material

The results of the measurements are presented in Fig. 6 and Fig. 7.

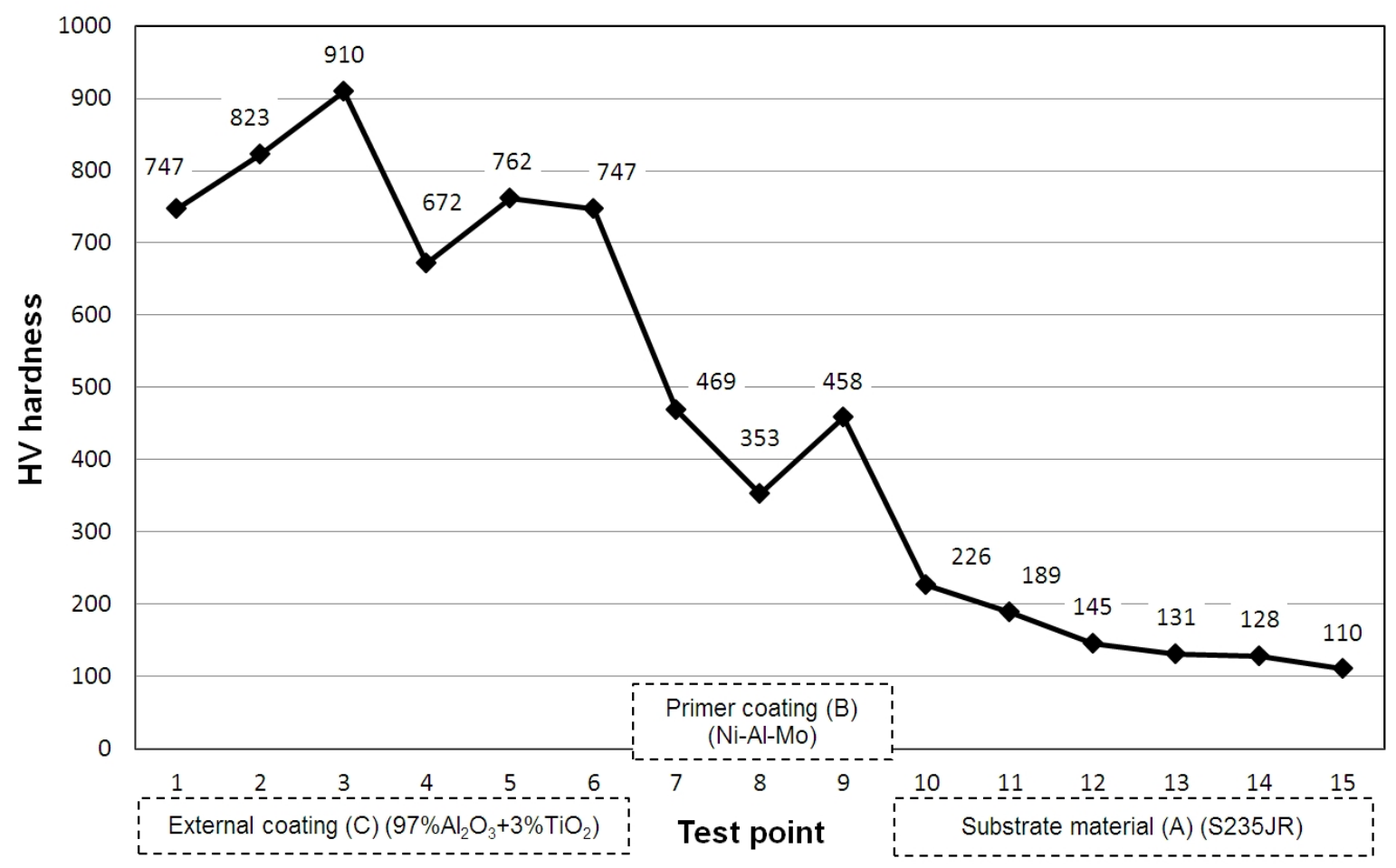

Fig. 6. Results of hardness measurement on cross section of sample after spraying with $97 \% \mathrm{Al}_{2} \mathrm{O}_{3}+3 \% \mathrm{TiO}_{2}$ powder 


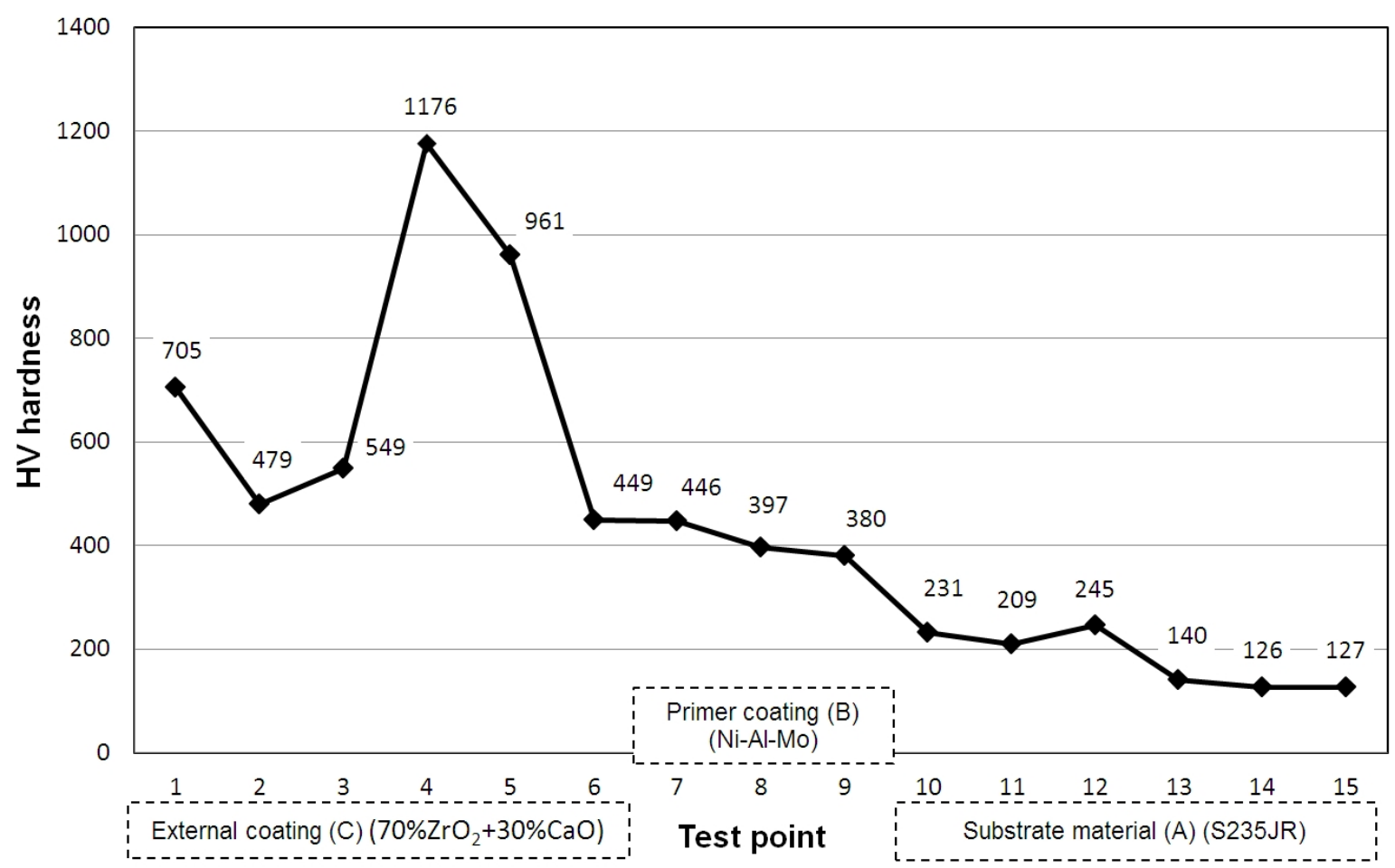

Fig. 7. Results of hardness measurement on cross section of sample after spraying with $70 \% \mathrm{ZrO}_{2}+30 \% \mathrm{CaO}$ powder

X-ray structure tests of the surface of the samples after flame spraying made with an X-ray diffractometer have enabled to determine the phase composition of the external specific surface made with aluminium oxide and zirconium oxide matrix powders on a substrate of a primer coating created using Ni-Al-Mo powder and a base material of S235JR low-carbon steel. The results of an X-ray qualitative analysis are shown in diffraction patterns, (Fig. 8, Fig. 9).

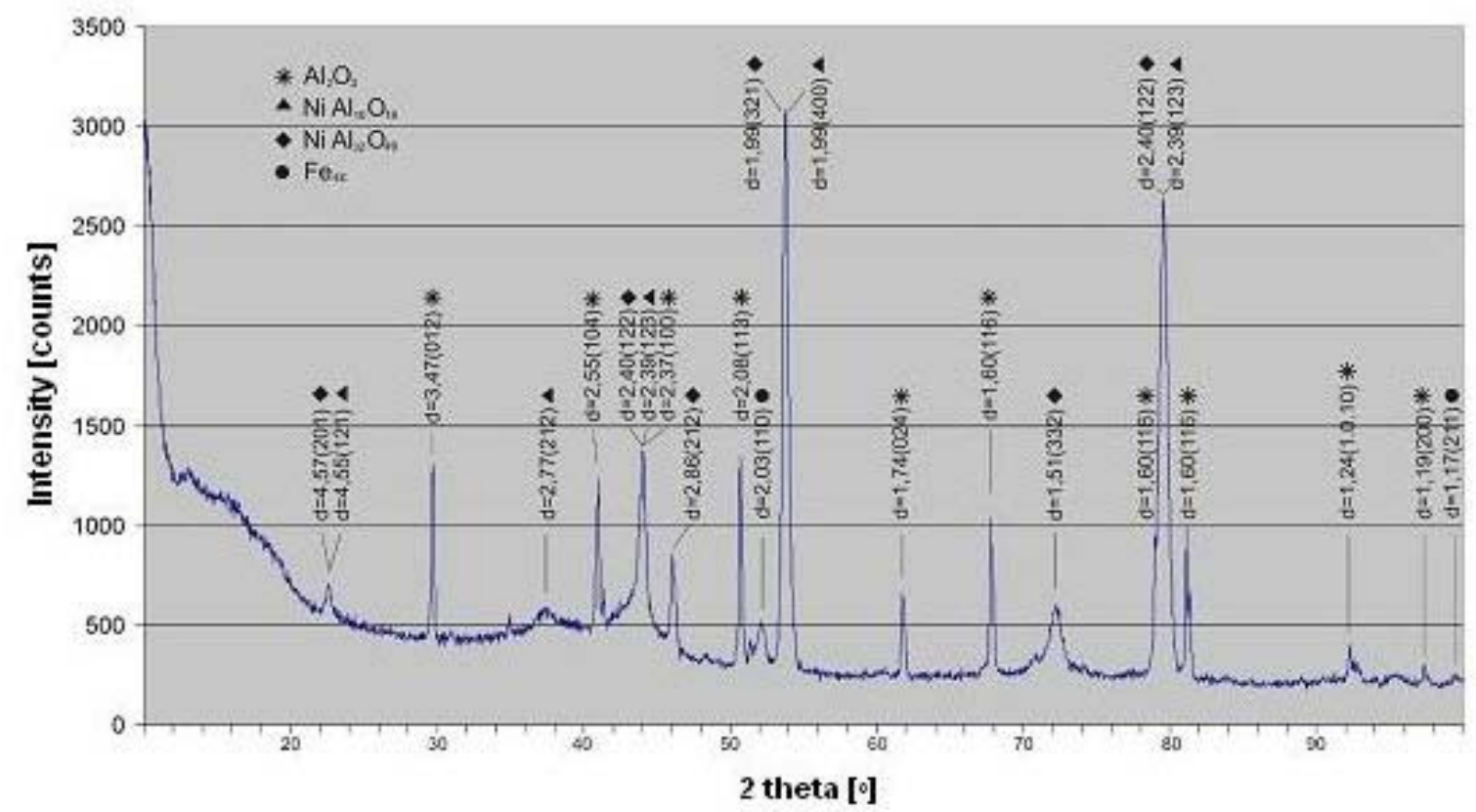

Fig. 8. Diffraction pattern of coating flame sprayed with $97 \% \mathrm{Al}_{2} \mathrm{O}_{3}+3 \% \mathrm{TiO}_{2}$ powder 




Fig. 9. Diffraction pattern of coating flame sprayed with $70 \% \mathrm{ZrO}_{2}+30 \% \mathrm{CaO}$ powder

a)

c)
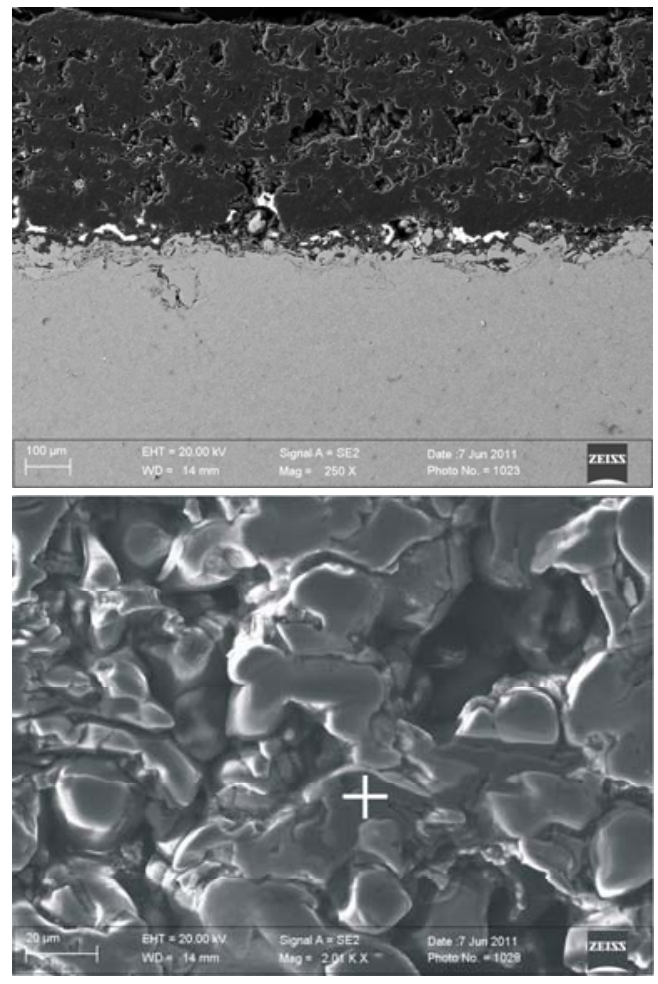

b)

d)

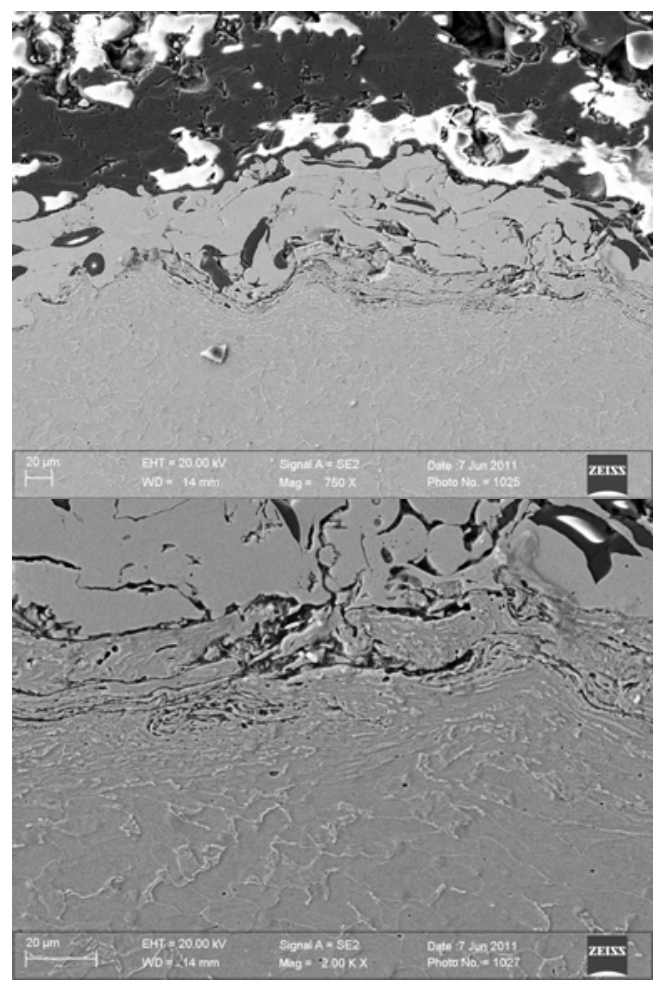

Fig. 10. View of coating after flame spraying with $97 \% \mathrm{Al}_{2} \mathrm{O}_{3}+3 \% \mathrm{TiO}_{2}$ powder: a) structure of external coating with primer coating and base material with visible hollows with varied size in external coating of sample; b) small amount of hollows in external coating in border area with primer coating; c) structure of external coating; d) area of base material and primer coating 


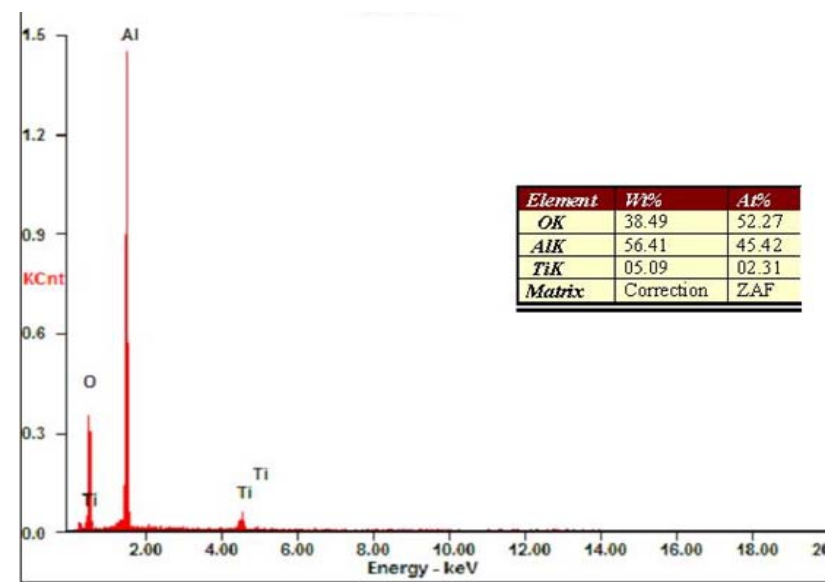

Fig. 11. Microanalysis of chemical composition of area from Fig. $10 \mathrm{c}$ )

The exact examinations of the structure of the coatings made were carried out with an electronic scanning microscope. Metallographic microsections were viewed with the magnification of 250 to 5000 times. The results of examinations with a scanning microscope have allowed to determine the influence of the type of the powder used in the spraying process on the structure of an external specific coating and a concentration of elements in selected microareas. The examples of observations of microstructures of the external coating and the primer coating are shown in Fig. 10 and Fig. 12, and a chemical composition microanalysis result is presented in Fig. 11 and Fig. 13.

a)

c)

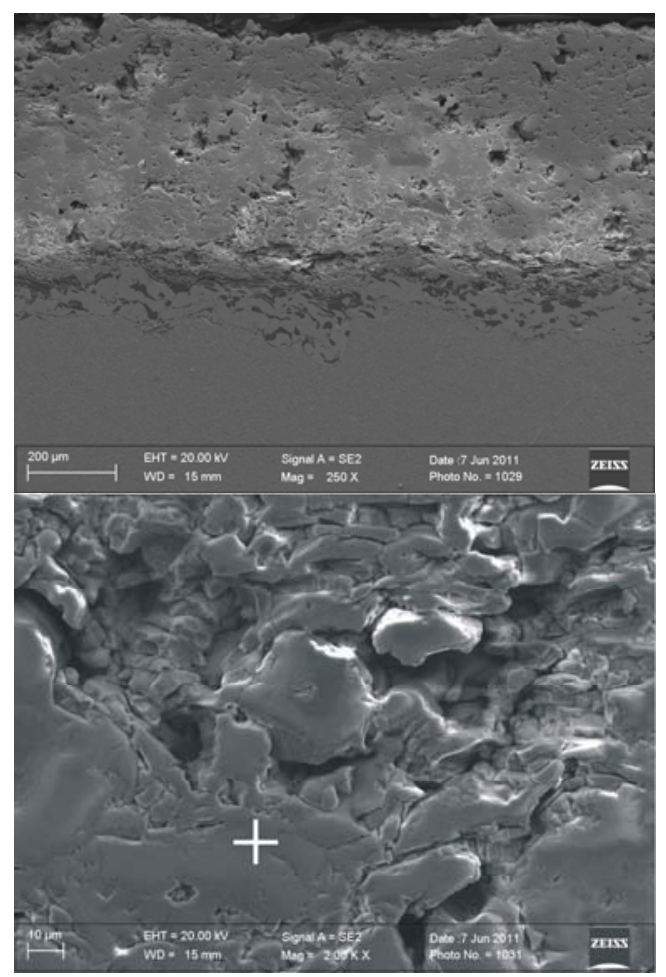

b)

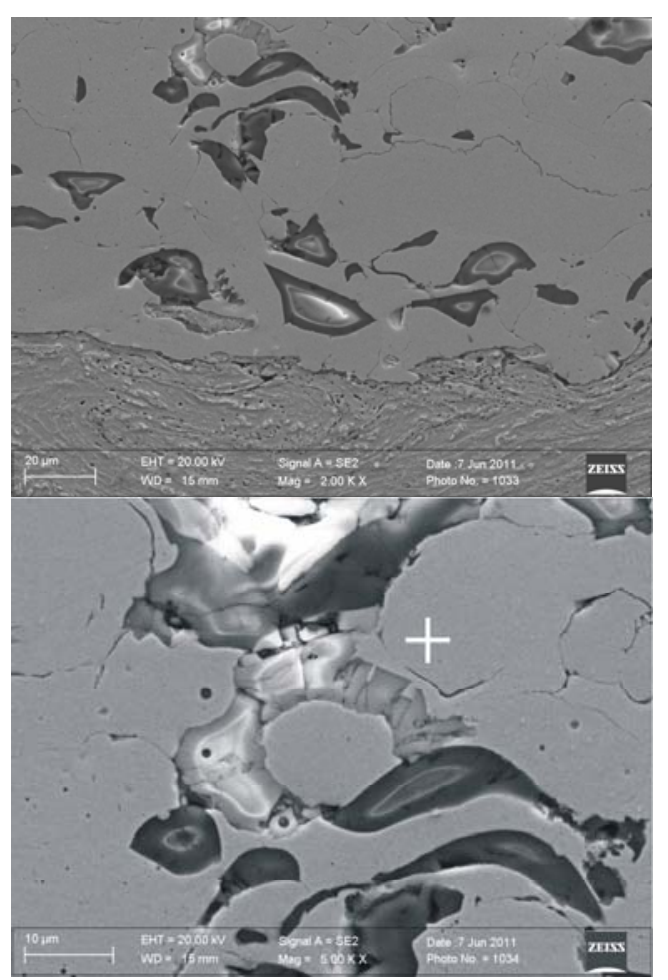

Fig. 12. View of coating after flame spraying with $70 \% \mathrm{ZrO}_{2}+30 \% \mathrm{CaO}$ powder: a) external coating with small amount of hollows; b) primer coating; c) structure of external coating; d) area of primer coating 
a)

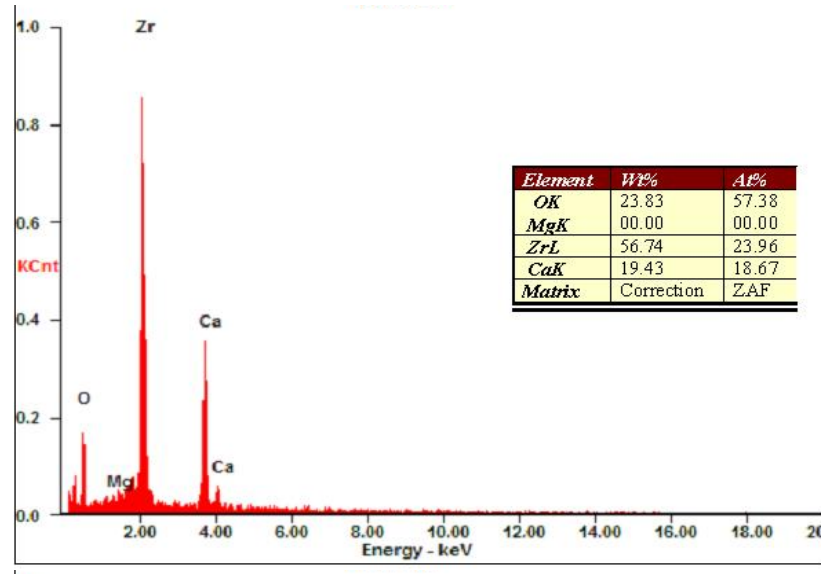

b)

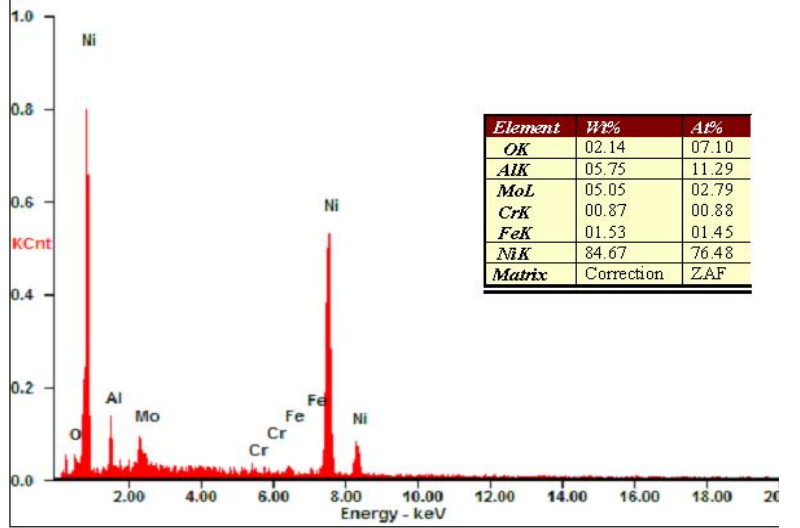

Fig. 13. Microanalysis of chemical composition of: a) area from Fig. 12 c); b) area from Fig. 12 d)

An abrasive wear resistance test of the mineral - mineral type of coatings sprayed with selected powders was performed on $5 \times 25 \times 75 \mathrm{~mm}$ samples in line with ASTM G65. The weight wear of the sample was determined as a result of the test, as determined after 100, 125, 250, 500 and 1500 revolutions of the abrasive pressure plate. The tests results have permitted to determine the abrasive wear resistance of the deposited coatings. The measurement results of abrasive wear resistance tests are presented in Table 3 .

An erosion resistance test was carried out in accordance with ASTM G76-95 on 5x25x75 mm samples with coatings deposited with $97 \% \mathrm{Al}_{2} \mathrm{O}_{3}+3 \% \mathrm{TiO}_{2}$ and $70 \% \mathrm{ZrO}_{2}+30 \% \mathrm{CaO}$ powders. Aluminium oxide $\left(\mathrm{Al}_{2} \mathrm{O}_{3}\right)$ powder with the particle diameter of $45 \div 70 \mu \mathrm{m}$ was used as an erosion material. The test was undertaken at the molecular velocity of $70 \pm 2 \mathrm{~m} / \mathrm{s}$, an erodent flow rate of approx. $2 \mathrm{~g} / \mathrm{min}$., nozzle outlet-to-sample distance of $10 \mathrm{~mm}$, and incidence angle of the abrasive stream of $90^{\circ}, 60^{\circ}, 30^{\circ}$ and $15^{\circ}$. The test lasted 10 minutes. The results of the tests are presented in Table 4 and Fig. 14. 
Table 3. Results of wear tests of coatings sprayed with $97 \% \mathrm{Al}_{2} \mathrm{O}_{3}+3 \% \mathrm{TiO}_{2}$ powder and $70 \% \mathrm{ZrO}_{2}+30 \% \mathrm{CaO}$ powder

\begin{tabular}{|c|c|c|c|c|c|c|c|c|}
\hline $\begin{array}{c}\text { Powder } \\
\text { composition }\end{array}$ & $\begin{array}{l}\text { Sample } \\
\text { No. }\end{array}$ & $\begin{array}{c}\text { Revolutions } \\
{[\mathrm{n}]}\end{array}$ & $\begin{array}{l}\text { Test } \\
\text { No. }\end{array}$ & \begin{tabular}{|c} 
Sample \\
weight prior \\
to test \\
{$[\mathrm{g}]$} \\
\end{tabular} & \begin{tabular}{|c} 
Sample \\
weight after \\
test \\
{$[\mathrm{g}]$} \\
\end{tabular} & $\begin{array}{c}\text { Mass loss } \\
{[\mathrm{g}]}\end{array}$ & $\begin{array}{c}\text { Average } \\
\text { mass loss } \\
{[\mathrm{g}]} \\
\end{array}$ & $\begin{array}{c}\text { Volume } \\
\text { loss } \\
{\left[\mathrm{mm}^{3}\right]}\end{array}$ \\
\hline \multirow{15}{*}{ 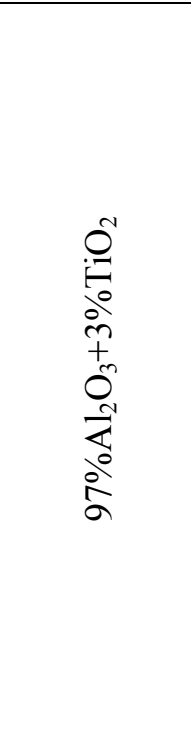 } & \multirow{3}{*}{ S 1.1} & \multirow{3}{*}{1500} & 1 & 75.8406 & 75.0086 & 0.832 & \multirow{3}{*}{0.8314} & \multirow{3}{*}{207.85} \\
\hline & & & 2 & 75.8396 & 75.0086 & 0.831 & & \\
\hline & & & 3 & 75.8395 & 75.0084 & 0.8311 & & \\
\hline & \multirow{3}{*}{ S 1.2} & \multirow{3}{*}{500} & 1 & 75.0825 & 74.6428 & 0.4397 & \multirow{3}{*}{0.4387} & \multirow{3}{*}{109.66} \\
\hline & & & 2 & 75.0821 & 74.6431 & 0.439 & & \\
\hline & & & 3 & 75.0802 & 74.6427 & 0.4375 & & \\
\hline & \multirow{3}{*}{ S 1.3} & \multirow{3}{*}{250} & 1 & 75.4531 & 75.2617 & 0.1914 & \multirow{3}{*}{0.1840} & \multirow{3}{*}{92.00} \\
\hline & & & 2 & 75.4524 & 75.2618 & 0.1906 & & \\
\hline & & & 3 & 75.4517 & 75.2816 & 0.1701 & & \\
\hline & \multirow{3}{*}{ S 1.4} & \multirow{3}{*}{125} & 1 & 75.8165 & 75.6092 & 0.2073 & \multirow{3}{*}{0.2074} & \multirow{3}{*}{51.85} \\
\hline & & & 2 & 75.8164 & 75.6091 & 0.2073 & & \\
\hline & & & 3 & 75.8167 & 75.6094 & 0.2073 & & \\
\hline & \multirow{3}{*}{ S 1.5} & \multirow{3}{*}{100} & 1 & 73.8637 & 73.7352 & 0.1285 & \multirow{3}{*}{0.1283} & \multirow{3}{*}{32.07} \\
\hline & & & 2 & 73.8635 & 73.7351 & 0.1284 & & \\
\hline & & & 3 & 73.8634 & 73.7355 & 0.1279 & & \\
\hline \multirow{15}{*}{ 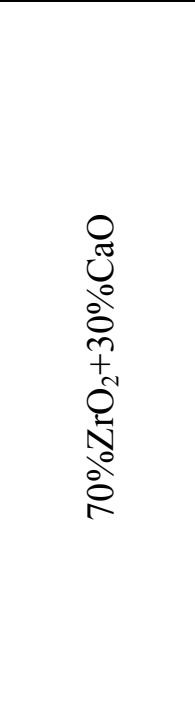 } & \multirow{3}{*}{ S 2.1} & \multirow{3}{*}{250} & 1 & 74.7266 & 74.0916 & 0.635 & \multirow{3}{*}{0.6347} & \multirow{3}{*}{112.34} \\
\hline & & & 2 & 74.7263 & 74.092 & 0.6343 & & \\
\hline & & & 3 & 74.7262 & 74.0915 & 0.6347 & & \\
\hline & \multirow{3}{*}{ S 2.2} & \multirow{3}{*}{500} & 1 & 77.6013 & 76.638 & 0.9633 & \multirow{3}{*}{0.9633} & \\
\hline & & & 2 & 77.6014 & 76.6378 & 0.9636 & & 170.49 \\
\hline & & & 3 & 77.6012 & 76.6381 & 0.9631 & & \\
\hline & & & 1 & 76.9207 & 75.458 & 1.4627 & & \\
\hline & S 2.3 & 1500 & 2 & 76.9205 & 75.4578 & 1.4627 & 1.4626 & 258.87 \\
\hline & & & 3 & 76.9206 & 75.4581 & 1.4625 & & \\
\hline & & & 1 & 76.8146 & 76.1956 & 0.619 & & \\
\hline & S 2.4 & 125 & 2 & 76.8148 & 76.1954 & 0.6194 & 0.6190 & 109.56 \\
\hline & & & 3 & 76.8143 & 76.1958 & 0.6185 & & \\
\hline & & & 1 & 78.5391 & 77.8907 & 0.6484 & & \\
\hline & S 2.5 & 100 & 2 & 78.5394 & 77.8905 & 0.6489 & 0.6485 & 114.78 \\
\hline & & & 3 & 78.5391 & 77.891 & 0.6481 & & \\
\hline
\end{tabular}

Table 4. Mass loss value in erosion tests of coatings sprayed with $97 \% \mathrm{Al}_{2} \mathrm{O}_{3}+3 \% \mathrm{TiO}_{2}$ and $70 \% \mathrm{ZrO}_{2}+30 \% \mathrm{CaO}$ powders

\begin{tabular}{|c|c|c|c|c|c|c|}
\hline \multirow{3}{*}{$\begin{array}{c}\text { Erodent } \\
\text { incidence angle } \\
{\left[^{\mathrm{O}}\right]}\end{array}$} & \multicolumn{6}{|c|}{ Type of powder sprayed } \\
\cline { 2 - 7 } & $\begin{array}{c}\text { Sample mass } \\
\text { prior to test } \\
{[\mathrm{g}]}\end{array}$ & $\begin{array}{c}\text { Sample mass } \\
\text { after test } \\
{[\mathrm{g}]}\end{array}$ & $\begin{array}{c}\text { Mass } \\
\text { loss } \\
{[\mathrm{g}]}\end{array}$ & $\begin{array}{c}\text { Sample mass } \\
\text { prior to test }[\mathrm{g}]\end{array}$ & $\begin{array}{c}\text { Sample mass } \\
\text { after test } \\
{[\mathrm{g}]}\end{array}$ & $\begin{array}{c}\text { Mass } \\
\text { loss } \\
{[\mathrm{g}]}\end{array}$ \\
\hline $90^{\circ}$ & 73.8752 & 73.8703 & 0.0049 & 75.9886 & 75.9560 & 0.0026 \\
\hline $45^{\mathrm{O}}$ & 73.8703 & 73.8485 & 0.0218 & 75.9560 & 75.9118 & 0.0442 \\
\hline $30^{\mathrm{O}}$ & 73.8485 & 73.8206 & 0.0279 & 75.9118 & 75.8640 & 0.0378 \\
\hline $15^{\mathrm{O}}$ & 73.8206 & 73.8027 & 0.0179 & 75.8640 & 75.8020 & 0.0620 \\
\hline
\end{tabular}


Powder type

$90^{\circ}$

$97 \% \mathrm{Al}_{2} \mathrm{O}_{3}+3 \% \mathrm{TiO}_{2}$

$70 \% \mathrm{ZrO}_{2}+30 \% \mathrm{CaO}$
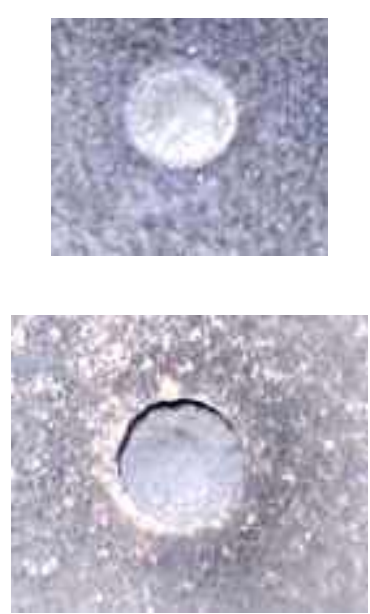

Erodent incidence angle $45^{\circ}$
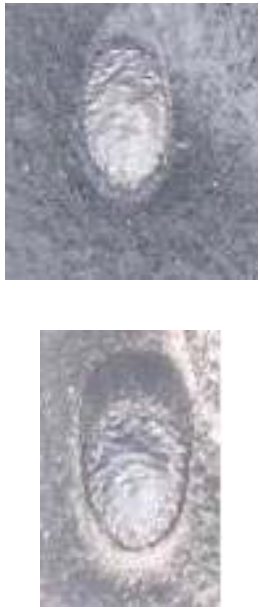

$30^{\circ}$

$15^{\circ}$
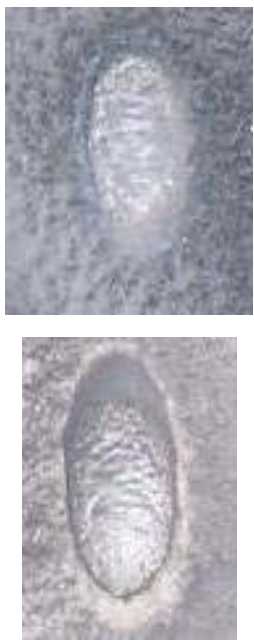

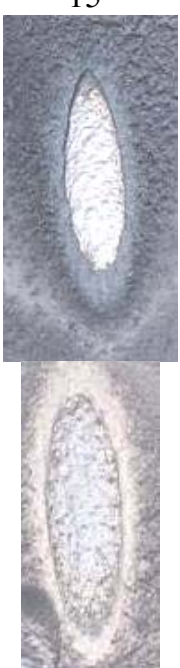

Fig. 14. View of surface after erosion tests

A coating adhesion test $\mathrm{R}_{\mathrm{h}}$ (stripping strength) was determined with the stripping method in a static tensile test in accordance with EN 582:1996 on cylindrical samples with the diameter of $\varnothing 40 \mathrm{~mm}$ flame sprayed with $97 \% \mathrm{Al}_{2} \mathrm{O}_{3}+3 \% \mathrm{TiO}_{2}$ and $70 \% \mathrm{ZrO}_{2}+30 \% \mathrm{CaO}$ powders. The face of the cylindrical samples with a coating deposited was bonded to a counterspecimen with Henkel Locit Hysol 3478 A\&B Superior Metal bonding agent with the tensile strength of $17 \mathrm{MPa}$. The samples, together with a fixing device, were placed in a tensile testing machine and were subjected to static stretching until rupture. Tensile test results allowed to determine the values of the force detaching the coatings from the substrate and to calculate an adhesion coefficient, (Fig. 15, Table 5).

Table 5. Results of adhesion tests of coatings sprayed with $97 \% \mathrm{Al}_{2} \mathrm{O}_{3}+3 \% \mathrm{TiO}_{2}$ and $70 \% \mathrm{ZrO}_{2}+30 \% \mathrm{CaO}$ powders

\begin{tabular}{|c|c|c|c|c|c|c|}
\hline \multirow{2}{*}{$\begin{array}{l}\text { Material of external } \\
\text { coating }\end{array}$} & \multirow{2}{*}{$\begin{array}{l}\text { Sample } \\
\text { No. }\end{array}$} & \multicolumn{2}{|c|}{ Sample size } & \multirow{2}{*}{$\begin{array}{c}\text { Maximum } \\
\text { breaking load } \\
{[\mathrm{N}]}\end{array}$} & \multicolumn{2}{|c|}{$\begin{array}{c}\text { Adhesion of } \\
\text { sprayed coating } \\
{\left[\mathrm{N} / \mathrm{mm}^{2}\right]}\end{array}$} \\
\hline & & $\begin{array}{c}\text { Sample } \\
\text { diameter } \\
{[\mathrm{mm}]}\end{array}$ & $\begin{array}{c}\text { Cross } \\
\text { section field } \\
{\left[\mathrm{mm}^{2}\right]}\end{array}$ & & $\mathrm{R}_{\mathrm{h}}$ & $\mathrm{R}_{\text {hśr }}$ \\
\hline \multirow{3}{*}{$97 \% \mathrm{Al}_{2} \mathrm{O}_{3}+3 \% \mathrm{TiO}_{2}$} & $1 / 1$ & 39.4 & 1218.6 & 7614.0 & 6.0 & \multirow{3}{*}{6.5} \\
\hline & $1 / 2$ & 39.0 & 1193.9 & 6418.0 & 5.4 & \\
\hline & $1 / 3$ & 39.8 & 1243.5 & 10095.0 & 8.1 & \\
\hline \multirow{3}{*}{$70 \% \mathrm{ZrO}_{2}+30 \% \mathrm{CaO}$} & $2 / 1$ & 39.8 & 1243.5 & 4104.0 & 3.3 & \multirow{3}{*}{3.3} \\
\hline & $2 / 2$ & 39.8 & 1243.5 & 4376.0 & 3.5 & \\
\hline & $2 / 3$ & 39.5 & 1224.8 & 3735.0 & 3.1 & \\
\hline
\end{tabular}

A thermal resistance test was carried out in line with ISO 14923:2003 on samples dimensioned $5 \times 25 \times 75 \mathrm{~mm}$ with an external $97 \% \mathrm{Al}_{2} \mathrm{O}_{3}+3 \% \mathrm{TiO}_{2}$ coating and an external $70 \% \mathrm{ZrO}_{2}+30 \% \mathrm{CaO}$ coating flame sprayed with powder. Three stages of the tests were determined as no detailed guidance was available concerning this type of tests:

- the first stage - heating to $1050^{\circ} \mathrm{C}$ and slow cooling together with an oven at a rate of $40^{\circ} / \mathrm{h}$, 
- the second stage - heating to $1050^{\circ} \mathrm{C}$ and cooling of samples in a stream of compressed air at a rate of $25 \%$, the cycle was repeated ten times;

the third stage - heating to $1050^{\circ} \mathrm{C}$ and sudden cooling of the samples in water at a rate of $100 \%$ s. The test result has identified the number of cycles after which discontinuities and delamination were visible on the coating surface, (Fig. 16).

a)

b)

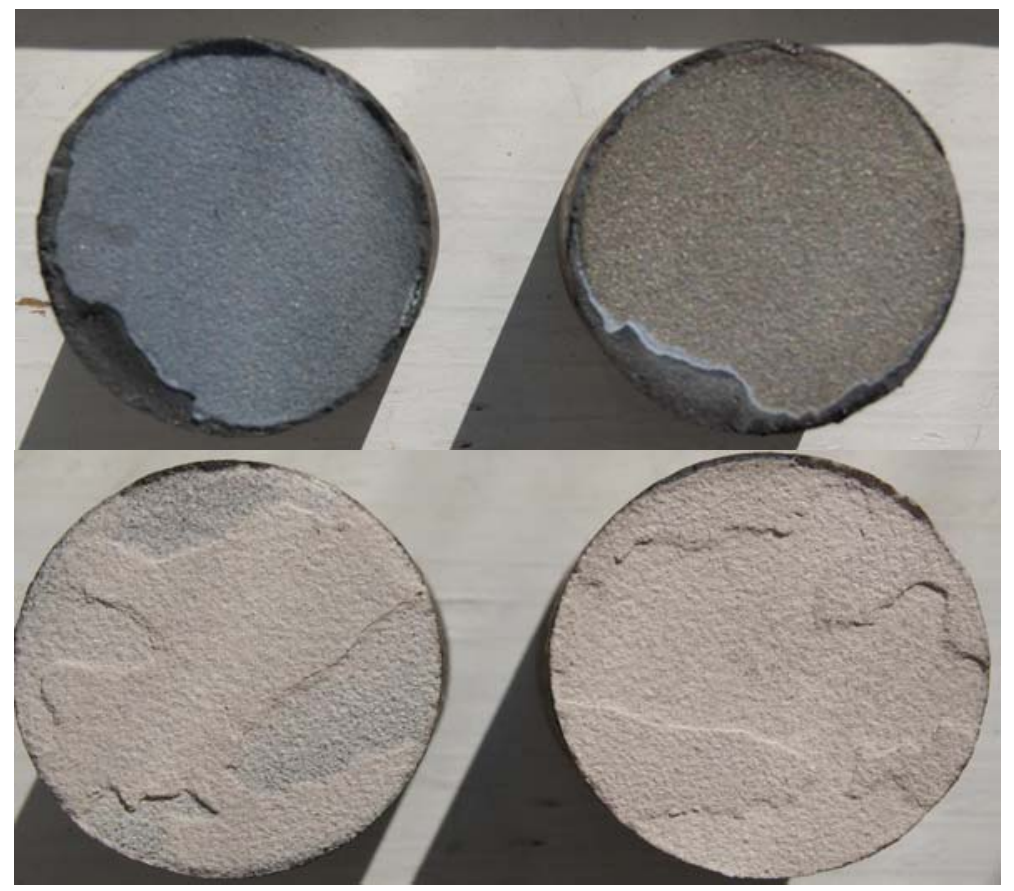

Fig. 15. The examples of fractures of samples with coatings sprayed with $97 \% \mathrm{Al}_{2} \mathrm{O}_{3}+3 \% \mathrm{TiO}_{2}$ powders and $70 \% \mathrm{ZrO}_{2}+30 \% \mathrm{CaO}$ powders after static tensile test: a) sample 1/1, b) 2/1, (Table 5)

a)

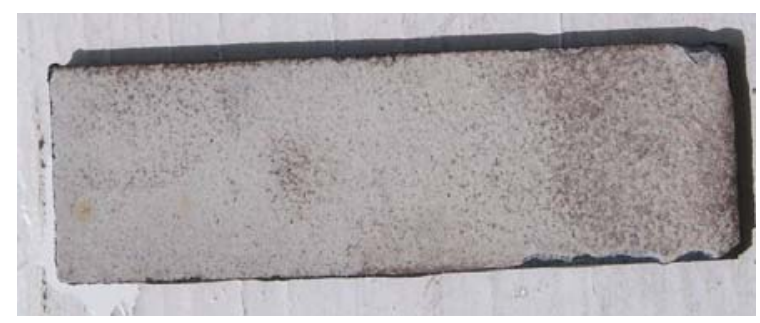

b)



c)

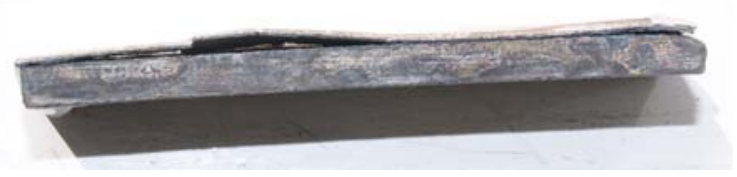

Fig. 16. View of samples after third stage of thermal resistance tests: a) surface of sample sprayed with $97 \% \mathrm{Al}_{2} \mathrm{O}_{3}+3 \% \mathrm{TiO}_{2}$ powder, b) cracks on the surface of coating sprayed with $70 \% \mathrm{ZrO}_{2}+30 \% \mathrm{CaO}$ powder, c) delamination of coating sprayed with $70 \% \mathrm{ZrO}_{2}+30 \% \mathrm{CaO}$ powder 
After carrying out a spraying process, the visual examinations made did not reveal any sample surface nonconformities after flame spraying with $97 \% \mathrm{Al}_{2} \mathrm{O}_{3}+3 \% \mathrm{TiO}_{2}$ and $70 \% \mathrm{ZrO}_{2}+30 \% \mathrm{CaO}$ powder. The metallographic examinations of the microsections perpendicular to the surface of the sample sprayed with $97 \% \mathrm{Al}_{2} \mathrm{O}_{3}+3 \% \mathrm{TiO}_{2}$ powder have shown that two coatings existed, respectively, on the surface of steel with developed surface line: a primer coating (B) and external specific coating (C), (Fig. 3 a)) A $30 \mu \mathrm{m}$ to $110 \mu \mathrm{m}$ thick primer coating (B) consisting of bright areas made of Ni-Al-Mo alloy and dark oxide inclusions, (Fig. $3 \mathrm{c}$ )), was observed immediately above the base material surface (A). A banded structure in the base material, distinctive for the strengthening of the steel surface during shot blasting of the examined material, existed in the boundary area with a primer coating. An external coating, formed in the spraying process, with its thickness varying between $450 \mu \mathrm{m}$ to $510 \mu \mathrm{m}$, existed in the primer coating. The coating possessed numerous voids with different size and a waved line of its external surface, (Fig. $3 \mathrm{~d}$ )).

A primer coating (B) and an external specific coating (C) existed on the steel surface with a developed surface line after spraying with $70 \% \mathrm{ZrO}_{2}+30 \% \mathrm{CaO}$ powder, (Fig. 4 a)). A banded structure with a considerable plastic deformation, existing on the thickness of approx. $50 \mu \mathrm{m}$, was observed underneath the primer coating in the steel. The primer coating consisted of bright areas of elements forming part of the Ni-Al-Mo powder used for spraying, and also of dark flattened oxides, (Fig. 4 c)). The coating was $50 \mu \mathrm{m}$ to $160 \mu \mathrm{m}$ thick. About a $600 \mu \mathrm{m}$ thick external specific coating possessed numerous voids with a developed line of its external surface, (Fig. 4 d)).

Hardness measurements were carried out on the microsections of samples from of a flame sprayed coating with $97 \% \mathrm{Al}_{2} \mathrm{O}_{3}+3 \% \mathrm{TiO}_{2}$ and $70 \% \mathrm{ZrO}_{2}+30 \% \mathrm{CaO}$ powder in microareas of the external coating $(\mathrm{C})$, primer coating(B) and the steel substrate (A), (Fig. 5). The specific external coating sprayed with $97 \% \mathrm{Al}_{2} \mathrm{O}_{3}+3 \% \mathrm{TiO}_{2}$ powder had the hardness of $671.8 \mathrm{HV} 5$ to 909.9 HV5, (Fig. 6). The hardness of the examined microareas in the primer coating was lower, i.e. 353 HV01 to 469 HV01. Hardness in the boundary zone with the primer coating in the substrate material was approx. $226 \mathrm{HV} 05$, as confirmed by the occurrence of a narrow heat-affected zone (HAZ) or by steel surface strengthening after shot blasting. The hardness of steel within approx. $500 \mu \mathrm{m}$ from steel was ca. $110 \mathrm{HV} 05$ and was characteristic for a ferritic structure with a small amount of cementite and perlite. The hardness of the external specific coating after a flame spraying operation with $70 \% \mathrm{ZrO}_{2}+30 \% \mathrm{CaO}$ powder was different and was between ca. 449 HV5 to ca. 961 HV5 (Fig. 7). Hardness measured on oxides with a larger area in the coating, in the places where oxide precipitates occurred, was even more than 1176 HV5. Different hardness results were caused by to a large number of voids in the coating. The hardness of the primer coating was from approx. $380 \mathrm{HV} 01$ to approx. 446 HV01, and of the primer material between 109 HV05 and 230 HV05. A deformed area of steel with a banded structure in the boundary zone with the primer coating exhibited the maximum hardness of 230 HV05.

$\mathrm{X}$-ray structure tests have allowed to identify phases existing in the structure of the coating after flame spraying with $97 \% \mathrm{Al}_{2} \mathrm{O}_{3}+3 \% \mathrm{TiO}_{2}$ and $70 \% \mathrm{ZrO}_{2}+30 \% \mathrm{CaO}$ powder, (Fig. 8 and Fig. 9). The existence of the $\mathrm{Al}_{2} \mathrm{O}_{3}, \mathrm{NiAl}_{10} \mathrm{O}_{16}$ and $\mathrm{NiAl}_{32} \mathrm{O}_{49}$ phase mainly, and also of trace amounts of $\mathrm{Fe} \alpha$ were identified after a spraying operation of the external coating with an aluminium matrix material, (Fig. 8). The examinations did not show the presence of a phase with titanium in this coating due to its small amount in the content of powder for spraying $\left(\mathrm{TiO}_{2}=3 \%\right)$. The phase can be identified with X-ray tests, provided it exists in the amount of more than $4 \%$. Ten diffraction lines from the phase $\mathrm{Al}_{2} \mathrm{O}_{3}$ were shown in a diffraction pattern, including with the maximum intensity from the planes (113), (116), (124), (030) and (1.0.10). Four diffraction lines coming from the planes (121), (212), (400) and (123) of $\mathrm{NiAl}_{10} \mathrm{O}_{16}$ 
phase and from the planes (201), (321), (332), (122) of $\mathrm{NiAl}_{32} \mathrm{O}_{49}$ oxide phase were also found. The existence of diffraction lines (100) and (211) with small intensity, coming from Fe $\alpha$, was also confirmed. The presence of compound zirconium and calcium oxides was also revealed in the structure of the external surface obtained after a spraying operation with $70 \% \mathrm{ZrO}_{2}+30 \% \mathrm{CaO}$ powder. 10 peaks deriving from the planes of the $\mathrm{CaZrO}_{3}$ phase and four peaks from the planes of the $\mathrm{Ca}_{0,15} \mathrm{Zr}_{0,85} \mathrm{O}_{1,85}$ phase occur in a diffraction pattern, (Fig. 9). The existence of peaks with small intensity from the planes (100) and (211), coming from Fe $\alpha$ steel surface, was also found.

A detailed examination of the inner structure of the coatings fabricated and the identification of chemical composition in microareas was performed with a scanning electron microscope. The external specific coating sprayed with $97 \% \mathrm{Al}_{2} \mathrm{O}_{3}+3 \% \mathrm{TiO}_{2}$ powder was not homogenous, (Fig. 10 a)). Voids with a diverse size of 10 to $100 \mu \mathrm{m}$ were identified. A small amount of voids was observed in the boundary area with the primer coating, (Fig. 10 b)). The width of the area was approx. $40 \mu \mathrm{m}$. The external coating was comprised of adjoining particles, (Fig. $10 \mathrm{c})$ ). It was concluded by way of a local microanalysis that aluminium, titanium, oxygen at a concentration of, respectively, 56.41\%, 5.09\% and $38.49 \%$, exist in such particles, (Fig. 11).

Much fewer voids were identified in the coating of a sample sprayed with $70 \% \mathrm{ZrO}_{2}+30 \% \mathrm{CaO}$ as compared to a coating sprayed with $97 \% \mathrm{Al}_{2} \mathrm{O}_{3}+3 \% \mathrm{TiO}_{2}$ powder, (Fig. 12 a)). The outcomes of the own unpublished investigations have shown that the number of voids in this coating was approx. 15\%. A microanalysis of an area shown in Fig. $12 \mathrm{c}$ ) has pointed out that zirconium, oxygen and calcium exist in its chemical composition, (Fig. 13 a)). A mass concentration of zirconium is $56.74 \%$, of oxygen of $23.83 \%$ and of calcium of $19.43 \%$. A microanalysis made in a primer coating of a sample created from NiAl-Mo powder sprayed with $70 \% \mathrm{ZrO}_{2}+30 \% \mathrm{CaO}$ powder has revealed the presence of $\mathrm{Ni}, \mathrm{Fe}$, Al, Mo, (Fig. 13 b)).

The results of a wear resistance test have permitted to conclude that a flame sprayed $97 \% \mathrm{Al}_{2} \mathrm{O}_{3}+3 \% \mathrm{TiO}_{2}$ coating was more resistant than a coating sprayed with $70 \% \mathrm{ZrO}_{2}+30 \% \mathrm{CaO}$ powder within the tested range of revolutions of 100 rev. to $1500 \mathrm{rev}$., (Table 3).

It was confirmed, based on erosion resistance tests, that a coating sprayed with $97 \% \mathrm{Al}_{2} \mathrm{O}_{3}+3 \% \mathrm{TiO}_{2}$ powder possesses higher erosion resistance (determined by mass loss) than a coating sprayed with $70 \% \mathrm{ZrO}_{2}+30 \% \mathrm{CaO}$ powder, except for testing at the angle of $90^{\circ}$, (Fig. 15). In case of erosion tests at the angle of $45^{\circ}, 30^{\circ}$ and $15^{\circ}$, a mass loss of a sample with a $93 \% \mathrm{Al}_{2} \mathrm{O}_{3}+3 \% \mathrm{TiO}_{2}$ coating was, respectively, $0.0218 \mathrm{~g}, 0.0279 \mathrm{~g}$ and $0.0179 \mathrm{~g}$, while of a sample with a $70 \% \mathrm{ZrO}_{2}+30 \% \mathrm{CaO}$ coating was about $50 \%$ higher, (Table 4 ).

The substrate adherence of flame sprayed coatings with $97 \% \mathrm{Al}_{2} \mathrm{O}_{3}+3 \% \mathrm{TiO}_{2}$ and $70 \% \mathrm{ZrO}_{2}+30 \% \mathrm{CaO}$ powder determined with a static stretching test until detaching a coating from the substrate has exhibited that the adherence of a coating sprayed with $97 \% \mathrm{Al}_{2} \mathrm{O}_{3}+3 \% \mathrm{TiO}_{2}$ powder was higher than of a coating made with $70 \% \mathrm{ZrO}_{2}+30 \% \mathrm{CaO}$ powder and was, respectively, 6.5 MPa, and 3.3 MPa, (Table 5). The difference between tensile strength and adhesion values was confirmed by inhomogeneous microsections of the samples' surface after a tensile test.

Thermal resistance was investigated with the method of cyclic heating to $1050^{\circ} \mathrm{C}$ and with cooling at a rate of $40^{\circ} \mathrm{C} / \mathrm{h}$ (with an oven), $25^{\circ} \mathrm{C} / \mathrm{s}$ (air cooling), $100^{\circ} \mathrm{C} / \mathrm{s}$ (water cooling) of samples coated on one side with $97 \% \mathrm{Al}_{2} \mathrm{O}_{3}+3 \% \mathrm{TiO}_{2}$ coating and $70 \% \mathrm{ZrO}_{2}+30 \% \mathrm{CaO}$ coating. After heating the samples to $1050^{\circ} \mathrm{C}$ and cooling with an oven in the first cycle of the test, with compressed air in the next nine cycles and cooling in water after the last cycle, a coating deposited with $70 \% \mathrm{ZrO}_{2}+30 \% \mathrm{CaO}$ powder has delaminated from the substrate and 
cracks were identified on it along with a detached coating, (Fig. $16 \mathrm{c}$ )). No damages in the form of delamination were identified for a coating deposited with $97 \% \mathrm{Al}_{2} \mathrm{O}_{3}+3 \% \mathrm{TiO}_{2}$ powder though, however, small cracks without broken-out sections were recorded, (Fig. 16 a).

\section{CONCLUSIONS}

The following conclusions have been formulated based on the investigations performed and the outcomes obtained and by analysing them:

1. Flame spraying with $97 \% \mathrm{Al}_{2} \mathrm{O}_{3}+3 \% \mathrm{TiO}_{2}$ and $70 \% \mathrm{ZrO}_{2}+30 \% \mathrm{CaO}$ powders carried out within the range of the selected parameters allowed to achieve high quality ceramic coatings approx. $500 \mu \mathrm{m}$ thick on a steel substrate.

2. The structure of a coating flame sprayed with $97 \% \mathrm{Al}_{2} \mathrm{O}_{3}+3 \% \mathrm{TiO}_{2}$ powder consisted mainly of aluminium oxide and a small amount of $\mathrm{NiAl}_{10} \mathrm{O}_{16}$ and $\mathrm{NiAl}_{32} \mathrm{O}_{49}$ phase, while a coating sprayed with $70 \% \mathrm{ZrO}_{2}+30 \% \mathrm{CaO}$ coating possessed a structure of oxide zirconium phases with calcium.

3. The bonding of a primer coating sprayed with Ni-Al-Mo powder with a steel substrate and of external coatings sprayed with $97 \% \mathrm{Al}_{2} \mathrm{O}_{3}+3 \% \mathrm{TiO}_{2}$ and $70 \% \mathrm{ZrO}_{2}+30 \% \mathrm{CaO}$ powders was of the mechanical adhesion nature. The ceramic coatings flame-sprayed with aluminium matrix powder and zirconium matrix powder were characterised by adhesion to the coating of, respectively: $6.5 \mathrm{MPa}$ and $3.3 \mathrm{MPa}$.

4. The coatings achieved, sprayed with $97 \% \mathrm{Al}_{2} \mathrm{O}_{3}+3 \% \mathrm{TiO}_{2}$ powder and $70 \% \mathrm{ZrO}_{2}+30 \% \mathrm{CaO}$ powder, possessed the average hardness of, respectively, approx. $780 \mathrm{HV}$ and approx. 720 HV.

5. The abrasive wear resistance of a coating sprayed with $97 \% \mathrm{Al}_{2} \mathrm{O}_{3}+3 \% \mathrm{TiO}_{2}$ powder was higher than the resistance of a coating sprayed with $70 \% \mathrm{ZrO}_{2}+30 \% \mathrm{CaO}$ powder, and average erosion wear resistance for the erodent incidence angle of less than $90^{\circ}$ was higher by approx. $50 \%$.

6. Cyclical heat stroke resistance was found for a coating sprayed with $97 \% \mathrm{Al}_{2} \mathrm{O}_{3}+3 \% \mathrm{TiO}_{2}$ powder, while a coating sprayed with $70 \% \mathrm{ZrO}_{2}+30 \% \mathrm{CaO}$ coating heated and cooled in the same conditions has revealed cracks, chippings and delamination.

\section{REFERENCES}

1. Janicki D.: High Power Diode Laser Cladding of Wear Resistant Metal Matrix Composite Coatings. Solid State Phenomena, Vol. 199 (2013), 587-592.

2. Arcondéguy A., Gasginier G., Montavon G., Pateyron B., Denoirjean A., Grimaud A., Huguet C.: Effects of spraying parameters onto flame-sprayed glaze coating structures. Surface \& Coatings Technology, Vol. 202 (2008), 4444-4448.

3. Lisiecki A.: Titanium Matrix Composite Ti/TiN Produced by Diode Laser Gas Nitriding. Metals, Vol 5(1) (2015), 54-59.

4. Janicki D.: Disk laser welding of armor steel. Archives of Metallurgy and Materials, Vol. 59 (2014), 1641-1646. 
5. Lisiecki A.: Welding of thermomechanically rolled fine-grain steel by different types of lasers. Archives of Metallurgy and Materials, Vol. 59 (2014), 1625-1631.

6. Kurc-Lisiecka A., Ozgowicz W., Ratuszek W., Kowalska J.: Analysis of Deformation Texture in AISI 304 Steel Sheets. Solid State Phenomena, Vol. 202-203 (2013), 105-110.

7. Adamiak M., Dobrzański L.A.: Microstructure and selected properities of hot-work tool steel with PVD coatings after laser surface treatment. Applied Surface Science, Vol. 254(15) (2008), 4552-4556.

8. Dobrzański L.A., Adamiak M.: Structure and properities of the TiN and Ti $(\mathrm{C}, \mathrm{N})$ coatings deposited in PVD process on high-speed steels. Journal of Materials Processing Technology, Vol. 133 (2003), 50-62.

9. Li J.F., Li L., Stott F.H.: Combined laser and flame surface coating of refractory ceramics: phase and microstructural characteristics. Thin Solid Films, Vol. 453-454 (2004), 67-71.

10. Pawlowski L., The Science and Engineering of Thermal Spray Coatings, second ed., John Wiley \& Sons, Chichester, UK, 2008.

11. Spencer K., Fabijanic D. M., Zhang M. X.: The use of Al-Al2O3 cold spray coatings to improve the surface properties of magnesium alloys. Surface and Coatings Technology, Vol 204 (2009), 336-344.

12. Vargas F., Ageorges H., Fournier P., Fauchais P., López M.E.: Mechanical and tribological performance of A12O3-TiO2 coatings elaborated by flame and plasma spraying. Surface \& Coatings Technology, Vol 205 (2010), 1132-1136. 